\title{
Competitive Rivalry, Social Disposition and Subjective Well-Being: An Experiment
}

Citation for published version (APA):

Riedl, A. M., Brandts, J., \& van Winden, F. (2009). Competitive Rivalry, Social Disposition and Subjective Well-Being: An Experiment. Journal of Public Economics, 93(11/12), 1158-1167.

https://doi.org/10.1016/j.jpubeco.2009.07.010

Document status and date:

Published: 01/01/2009

DOI:

10.1016/j.jpubeco.2009.07.010

Document Version:

Publisher's PDF, also known as Version of record

Document license:

Taverne

Please check the document version of this publication:

- A submitted manuscript is the version of the article upon submission and before peer-review. There can be important differences between the submitted version and the official published version of record.

People interested in the research are advised to contact the author for the final version of the publication, or visit the DOI to the publisher's website.

- The final author version and the galley proof are versions of the publication after peer review.

- The final published version features the final layout of the paper including the volume, issue and page numbers.

Link to publication

\footnotetext{
General rights rights.

- You may freely distribute the URL identifying the publication in the public portal. please follow below link for the End User Agreement:

www.umlib.nl/taverne-license

Take down policy

If you believe that this document breaches copyright please contact us at:

repository@maastrichtuniversity.nl

providing details and we will investigate your claim.
}

Copyright and moral rights for the publications made accessible in the public portal are retained by the authors and/or other copyright owners and it is a condition of accessing publications that users recognise and abide by the legal requirements associated with these

- Users may download and print one copy of any publication from the public portal for the purpose of private study or research.

- You may not further distribute the material or use it for any profit-making activity or commercial gain

If the publication is distributed under the terms of Article $25 \mathrm{fa}$ of the Dutch Copyright Act, indicated by the "Taverne" license above, 


\title{
Competitive rivalry, social disposition, and subjective well-being: An experiment
}

\author{
Jordi Brandts ${ }^{a}$, Arno Riedl ${ }^{\mathrm{b}, *}$, Frans van Winden ${ }^{\mathrm{c}}$ \\ a Department of Business Economics, Univ. Autònoma de Barcelona, Institute for Economic Analysis (CSIC) and Barcelona GSE, Campus UAB, Bellaterra, Barcelona, Spain \\ b IZA, CESifo, and Maastricht University, Department of Economics (AE 1), Faculty of Economics and Business Administration, P.O. Box 616, NL-6200 MD Maastricht, The Netherlands \\ c Tinbergen Institute and University of Amsterdam, CREED, Faculty of Economics and Business, Roetersstraat 11, NL-1018 WB Amsterdam, The Netherlands
}

\section{A R T I C L E I N F O}

\section{Article history:}

Received 23 February 2007

Received in revised form 12 July 2009

Accepted 22 July 2009

Available online 14 August 2009

\section{JEL classification:}

A13

C92

D30

550

M50

Keywords:

Competition

Rivalry

Happiness

Well-being

Laboratory

Experiment

Emotions

\begin{abstract}
A B S T R A C T
This paper experimentally studies the effects of competitive rivalry in a social dilemma where people's actions cannot be contractually fixed. We find that, in comparison with no rivalry, the presence of rivalry does neither increase efficiency nor does it yield any gains in earnings for the short side of the exchange relation. Moreover, rivalry has a clearly negative impact on the disposition towards others and on the experienced well-being of those on the long side. Since subjective well-being improves only for those on the short side rivalry contributes to larger inequalities in experienced well-being. All in all rivalry does not show up as a positive force in our environment.
\end{abstract}

(c) 2009 Elsevier B.V. All rights reserved.

\section{Introduction}

In this paper, we experimentally investigate the consequences of competitive rivalry in a situation without formal contracting possibilities. Our study builds upon the idea that (social) preferences and tastes may not be independent of the institutional environment. For instance, Bowles (1998) argues that different kinds of institutions may affect values, tastes and personalities. A particularly important issue he discusses is closely related to the concern about the effect that rivalry can have on well-being. In his own words: “(...) there are significant differences in the personality effects on participants in markets (...) for people on the short side (...) and those on the long side of the market, some of which are simply excluded from the exchange process, while others fear losing the transactions they have secured" (Bowles, 1998, p. 78). This statement suggests that people's

\footnotetext{
* Corresponding author.

E-mail addresses: Jordi.Brandts@uab.cat (J. Brandts), a.riedl@maastrichtuniversity.nl (A. Riedl), f.a.a.m.vanwinden@uva.nl (F. van Winden).
}

well-being is influenced by the competitiveness of the environment and the side one is on in such an environment. ${ }^{1}$

There are several reasons why it is important to investigate the relationship between competitive rivalry and well-being. For one, well-being and happiness are undoubtedly central goals in human life. ${ }^{2}$ This by itself is an important reason for studying their relation to different economic institutions. In addition, there is considerable evidence that supports the premise that satisfaction with process and procedures is an important ingredient of human motivation. ${ }^{3}$ The degree of competitiveness may be viewed as one aspect of the

\footnotetext{
${ }^{1}$ In a similar vein, Rabin (1993, p. 1283) argues that: "Welfare economics should be concerned not only with the efficient allocation of material goods, but also with designing institutions such that people are happy about the way they interact with others."

${ }^{2}$ Kahneman et al. (1999) provide a wealth of information about the importance of well-being (see also, Frey and Stutzer, 2002; Ferrer-i-Carbonell, 2005; Krueger 2005 McFadden, 2005).

${ }^{3}$ Kahneman et al. (1986), Barrett-Howard and Tyler (1986), and Bies et al. (1993) find that procedural information influences judgments of market exploitation. Charness and Levine (2000) find that perceived fairness of a layoff is highly dependent on the manner in which the layoff is implemented and Bolton et al. (2005) show that different random procedures affect choice behavior.
} 
procedure under which interaction takes place. Beyond these direct consequences of rivalry on well-being there are potentially also derived consequences. Specifically, interacting under rivalry may change people's disposition towards others and, in particular, towards those individuals they have encountered in the interaction, and whom they may meet again in the future. These potential effects of rivalry have not received much attention in economics, but need to be studied in order to get a more complete picture of the impact of rivalry on economic and social life. We investigate both the direct as well as the derived effects of rivalry on well-being.

A stream of theoretical studies-initiated by Akerlof's (1970) seminal 'Lemons Market' paper-has shown that competition does not guarantee allocative efficiency in environments that are characterized by contractual incompleteness (cf. Klein and Leffler, 1981; Levin, 2003). Experimental studies of exchange situations where formal contracts are incomplete or absent have corroborated this view and, moreover, shown that the validity of economic analysis based on standard assumptions of narrow selfishness and rationality may be considerably limited (Fehr et al., 1993, 1998; Fehr et al., 1997; Fehr and Falk, 1999; Hannan et al., 2002; Brown et al., 2004; Brandts and Charness, 2004). These studies have greatly increased our knowledge about the problems and possible solutions of exchange situations without complete contracts. However, there is still a lack of knowledge and evidence of the effect of rivalry per se in such contract situations.

Our experimental design allows us to control for the effects of rivalry as such, in an environment with incomplete contracting. We compare subjects' behavior in several experimental conditions with rivalry and in one condition without rivalry, while holding all other aspects of the economic environment constant. In our design it is completely transparent whether one is interacting under rivalry or not, and it appears in such a way that it is always clear who is on the long or short side of the interaction. Another important feature of our design is that we collect data about participants' subjective well-being and disposition towards others, which allows us to study the impact of rivalry on well-being and disposition towards others in a controlled way. In the environments with rivalry we can also distinguish between effects on the short and on the long side of the interaction. We further study how subjective well-being and disposition towards others are related to interaction success in the different conditions.

\section{Design and procedures}

Our experimental set-up consists of one condition without rivalry and three conditions with rivalry, each consisting of three parts. In part 1 subjects make decisions in the circle test, a task designed to elicit people's initial disposition towards others. Part 2 is a finitely repeated social dilemma game played by a fixed group of subjects under different rivalry conditions. In part 3 , we measure the repercussions of what occurs in the interactive phase, by eliciting participants' subjective general well-being and experienced emotions, followed by a second application of the circle test measuring subjects' post-interaction disposition towards their interaction partners. Table 1 depicts the sequence of events. In the following we present each of these parts in detail. The four conditions differ with respect to the interactive game played in part 2 . We, therefore, start with the description of this part.

\section{Part 2 - The interactive game}

In this part we compare behavior in four environments: one without rivalry and three different ones with rivalry. In the No Rivalry Condition (hereafter NRC) the repeated game is played in a dyad, by a pair of fixed partners, labeled A and B. In contrast, in the three Rivalry Conditions (hereafter RCs), the game involves a triad of fixed players with fixed roles: A, B and C (cf. Davis and Holt, 1994). Such ongoing
Table 1

Sequence of events.

\begin{tabular}{|c|c|}
\hline \multicolumn{2}{|c|}{ General information $\rightarrow$ experiment consists of three parts } \\
\hline \multicolumn{2}{|l|}{ Part 1} \\
\hline \multirow{2}{*}{\multicolumn{2}{|c|}{$\begin{array}{l}\text { Instructions for first circle test only } \\
\text { Circle test measuring disposition towards random stranger }\end{array}$}} \\
\hline & \\
\hline \multicolumn{2}{|l|}{ Part 2} \\
\hline \multicolumn{2}{|c|}{ Instructions for interactive game } \\
\hline In NRC & In RC-90, RC-90DC or RC-10 \\
\hline Interaction in dyad & Interaction in triad \\
\hline \multicolumn{2}{|l|}{ Part 3} \\
\hline \multirow{3}{*}{\multicolumn{2}{|c|}{$\begin{array}{l}\text { Measurement of general subjective well-being } \\
\text { Measurement of specific emotions } \\
\text { Instructions for second circle test }\end{array}$}} \\
\hline & \\
\hline & \\
\hline In NRC & In RC-90, RC-90DC or RC-10 \\
\hline $\begin{array}{l}\text { Circle test measuring disposition towards } \\
\text { partner and random stranger }\end{array}$ & $\begin{array}{l}\text { Circle test measuring disposition } \\
\text { towards both interaction partners }\end{array}$ \\
\hline
\end{tabular}

relationships, which are characteristic of many if not most market and organizational environments, are the natural context in which to study the issues at hand. It opens the possibility for the creation of emotional and social ties (Lawler et al., 1995; van Dijk and van Winden, 1997) and for more general psychological effects of rivalry to accumulate over time. The three rivalry conditions will be denoted by RC-90, RC-90DC and RC-10 for reasons that will be explained shortly.

In all four conditions the number of repetitions (rounds) is 30 . In each round of the game of the three RCs the subject in the role of A has to choose to play either with B or with C. Since player A can only choose one of the other two players the situation of players with roles B and C is one of rivalry as defined by Stigler (1987), who writes, that "competition is a rivalry between individuals (or groups or nations), and it arises whenever two or more parties strive for something that all cannot obtain" (p. 531). Thus, the RCs reflect in a simple but effective way the kind of rivalry we want to study. ${ }^{4}$

The stage game of the repeated social dilemma game implemented in part 2 is shown in Fig. 1. The representation corresponds directly to the NRC condition, where the game is played by two fixed partners, A and $B$. In each round the two players simultaneously choose between the numbers 0 and 10 . The choice possibilities represent 'cooperation' and 'no cooperation' in a social dilemma situation and may be interpreted as, e.g., wage and effort choices in a gift-exchange framework or quality and price choices in markets of experience goods. Below, we refer to the choices in terms of (rates of) cooperation.

The RCs involve one more choice for one of the players. In each round of these conditions, player A also chooses between two partners, B and C. Player A and the chosen partner then play the above game while the not chosen player obtains a fixed payment. The unchosen player is not informed about the outcome of the interaction between the A player and the chosen player. The $\mathrm{B}$ and $\mathrm{C}$ labels are kept constant throughout the interaction so that A can trace the history of B's and C's play. Note that at the outset the B and C players are identical.

The fact that both A and the chosen partner can freely choose their action in a round represents the absence of formal contracting on both sides of the relation. We consider this to be more interesting than the case of one-sided completeness in which one side's responsibilities

\footnotetext{
${ }^{4}$ With this design we capture the essential aspects of competitive rivalry. However, we do not claim to examine all potentially interesting facets of competition. In particular, we do not deal with the kind of full-fledged atomistic competition involving a large number of participants that is often studied in economics. We also do not study other potentially important features of competition like how it contributes to an efficient allocation of resources by leading to trade by high-valuation buyers and lowcost sellers.
} 


\section{$0 \quad 10$

$0 \quad 160,160 \quad 410,40$ \\ $10 \quad 40,410 \quad 290,290$ \\ In RC-90 and RC-90DC the player not chosen receives 90, in $\mathrm{RC}-10$ the player not chosen receives 10 .}

Fig. 1. The stage game

are completely fixed. It also makes the players symmetric with respect to the choice possibilities. This is a desirable feature because we want to isolate the effect of rivalry from possible influences related to choice or payoff asymmetries. This is also the reason why the players are symmetric with respect to the payoffs. This symmetry facilitates a straightforward comparison of behavior and earnings across different conditions and player types.

The three conditions with rivalry differ with respect to the timing of the $\mathrm{B} / \mathrm{C}$ choices and the value of the payoff that the unchosen player obtains. In our RC-90 condition subjects in the role of B and C made their choice before they knew whether they had been chosen by $A$ and the unchosen $\mathrm{B} / \mathrm{C}$ player obtained a payoff of 90 . This choice procedure for $\mathrm{B}$ and $\mathrm{C}$ yields more information than a sequential choice set-up and also allows us to compare the behavior of chosen and unchosen players. Subjects' information depended on the role they were in: in each round, player A was only informed about the choice of the selected player and the B or C player was only informed of A's choice if he had been selected. In our view, this information structure is quite natural since in many economic exchange situations the terms of the implicit contract are typically not revealed to third parties. The outside payoff of 90 is dominated by the payoffs that a B/C player can obtain if he is chosen by $A$ and chooses 0 . At the same time, it is higher than what he gets if he is cooperating but exploited by A.

It is conceivable that the choice procedure used in RC-90 could have a separate effect on behavior, perhaps eliciting a very studied, non-spontaneous reaction by B and C. To explore this possibility we changed, in the condition denoted by RC-90DC (where DC refers to direct choice), the choice procedure, while leaving everything else as in RC-90. In RC-90DC the A player first selects whether he will play with $\mathrm{B}$ or $\mathrm{C}$, the chosen $\mathrm{B} / \mathrm{C}$ player is then informed about this, and then the two players make their choices between 0 and 10 .

In our RC-10 condition we used the same choice procedure as in RC-90, but lowered the payment of the unchosen player to 10 . An intuitive conjecture is that this will lead to more cooperation by $\mathrm{B} / \mathrm{C}$ players, as being left out is now very costly to them.

The game-theoretic predictions based on the standard assumption of (common knowledge of) rationality and narrow material selfinterest differ across the conditions. For the NRC the unique prediction is straightforward. Since the stage game has the incentive structure of a prisoners' dilemma game, both players choose 0 in the unique Nash equilibrium. Consequently, the repeated game has also only one Nash equilibrium, which is subgame-perfect: both players choose 0 in each round.

For the RCs the standard predictions are rather different. The stage game now has two Nash equilibria in pure strategies in which all three players involved choose action 0 . The equilibria differ in whether $\mathrm{A}$ chooses B or C as partner and they are not payoff-equivalent. As a consequence of the latter, our finitely repeated RC games also have multiple subgame-perfect Nash equilibria. One involves all three players choosing the non-cooperative choice in every round. However, there are also numerous other subgame-perfect Nash equilibria involving different levels of stable relations between player A and his partners and different degrees of gains from cooperation for different players. ${ }^{5}$ The equilibria for RC-90 and RC-90DC are the same. Lowering of the outside payoff to 10 as in RC-10 slightly enlarges the set of subgame-perfect equilibria with cooperation. Hence, even

\footnotetext{
${ }^{5}$ For details see the working paper version of our study (Brandts et al., 2008).
}

under the standard game-theoretic assumptions there are subgameperfect Nash equilibria that imply considerable cooperation in the different rivalry conditions, but not in the NRC. ${ }^{6}$

The theoretical prediction of multiple equilibria with and without gains from cooperation in our RCs is akin to the findings of MacLeod and Malcomson (1989). They show that in repeated labor relations without contractually complete effort enforcement many equilibria exist. Some of them involve cooperation with rent extraction whereas others are equivalent to the competitive Walrasian outcome without any rents.

\section{Part 1 - Initial disposition towards others}

In part 1 we recorded participants' decisions in the circle test, which is a modified version of the ring test (Liebrand, 1984) and was successfully applied by Sonnemans et al. (2006). It is a task which allows for a quantification of people's disposition towards others by determining the readiness of individuals to help or hurt others at some cost to themselves.

In the circle test a person's disposition towards another person is measured by a decision which consists in the selection of a point on a circle. (For a visualization we refer the reader to Brandts et al., 2008.) Each point on the circle represents an allocation of points to the person who makes the choice $(S)$ and to another person $(0)$. Tracing the vertical projection to the horizontal axis one can find the amount $S$ obtains and tracing the horizontal projection to the vertical axis one finds the quantity that $O$ obtains. All amounts can be positive or negative, with $S^{2}+O^{2}=1000^{2}$. It is possible to choose $S=1000$ and $O=0$. Any other choice of $O$ leads to $S<1000$. Importantly, in the experiment these numbers translate into money earnings at the exchange rate of 1000 points equal to $€ 2.30$. Hence, decisions in the circle test have pecuniary consequences. When presenting the results we will refer to the chosen points in terms of the angle formed by the ray, which connects the chosen point on the circumference to the origin, and the horizontal axis. For example, an angle of $0^{\circ}$ means selfish preferences, whereas $90^{\circ}$ means that one maximizes the other's payoff leaving nothing for oneself, and $45^{\circ}$ means equal positive payoffs. Angles larger than $180^{\circ}$ are described as negative. For instance $-90^{\circ}$ means to maximize the other's losses and keeping nothing for oneself, $-45^{\circ}$ means keeping the same amount the other loses, and a small negative angle represents keeping most of the money for oneself while spending a little bit on taking away some money from the other person. ${ }^{7}$

In all conditions subjects had to make circle-test decisions with respect to other subjects. Before the interactive phase of part 2 began and before even knowing the content of this phase, thus also not knowing whether they were in the NRC or a rivalry condition, each subject chose an angle with respect to one anonymously and randomly chosen other subject. These initial angles towards a stranger measure the 'social value orientation' or the disposition towards generalized others. Subjects were not informed about the decision of 'their' strangers in the circle test until the very end of the session.

\footnotetext{
${ }^{6}$ Social or other-regarding preferences can transform the social dilemma games into coordination games in all conditions and can therefore lead to cooperation in the RCs as well as the NRC. For instance, with the type of distributional preferences posited by Fehr et al. (1998), Fehr and Schmidt (1999) or Bolton and Ockenfels (2000) both our stage games can have an equilibrium without cooperation, but also have equilibria in which some subjects cooperate while others defect. Other models of social preferences like Dufwenberg and Kirchsteiger (2004), Falk and Fischbacher (2006) and Charness and Rabin (2002) predict similar patterns.

7 The circle test has the advantages of allowing subjects to subtract from others payoffs in a symmetric way, in the sense that giving, e.g., 10 points has the same material costs as taking away 10 points. Especially, in our context where negative and positive emotions may come into play this seems to be an advantage over the use of the more standard dictator game for eliciting social dispositions. In the experiment the circle appeared on subjects' computer screen. Subjects received computerized instructions about how to make the decision and had ample opportunity to practice.
} 
Part 3 - Post-interaction well-being and disposition towards others

In part 3 of the experiment we measured the effects of the interaction in the game on subjects' subjective well-being and emotions ${ }^{8}$ as well as their dispositions towards others.

After the last round of the interactive game, and without knowing beforehand, subjects had to respond to a computerized questionnaire designed to elicit participants' subjective well-being. They were asked to rate themselves with respect to a general subjective well-being indicator as well as with respect to thirteen specific emotions. ${ }^{9}$ The questionnaire used has previously successfully been applied by Bosman and van Winden (2002). We will explain the general measure of subjective well-being and the emotions questionnaire in detail when we present the results on them in Section 3.2.

To measure the impact of interaction experience on the disposition towards others, subjects had to make two new circle-test decisions, right after answering the questionnaires. In the RCs each subject chose angles regarding each of the two other subjects in the triad. In the NRC each subject made one choice regarding his partner and-to keep the number of decisions constant across conditions-another choice regarding a randomly chosen third anonymous subject. ${ }^{10}$

In summary, our discussion leads us to the following main working hypotheses. First, in the interactive game, standard theory predicts either the same or more cooperation (i.e., efficiency) in treatments with rivalry and either no earnings advantage or an earnings advantage of the A player; the results pertaining to this hypothesis are presented in Section 3.1. Second, we hypothesize that experience of rivalry has a negative effect on subjective well-being and on disposition towards others of the $\mathrm{B} / \mathrm{C}$ players who can be excluded from the interaction; this is analyzed in Sections 3.2 and 3.3. Third, we expect that interaction success in terms of monetary earnings, the presence of rivalry and the player role together with the subjective well-being and emotions interact in affecting players' social postgame disposition towards others; this is what we study in Section 3.4.

\section{Results}

We collected data for 293 subjects. Each subject participated in only one session. For the NRC 72 subjects participated in 36 dyads in four NRC sessions. We conducted four sessions with each of the three RCs. We had 81 subjects in RC-90, 75 in RC-90DC and 66 in RC-10. We have, therefore, $26[36]^{11}, 27,25$ and 22 statistically independent observations for the different conditions. All sessions were run computerized at the CREED laboratory at the University of Amsterdam. The average (net of show-up fee) earnings per subject was $€ 23$. A typical session lasted approximately 90 min.

We start with the results related to material efficiency and earnings in the different treatments. Main findings will be formulated in terms of a number of specific results. ${ }^{12}$

\footnotetext{
${ }^{8}$ We use the notion subjective well-being similarly to Kahneman et al.'s (1997) notion of 'experienced utility', which goes back to Bentham. As these authors we claim that 'subjective well-being' is both measurable and empirically distinct from standard decision utility. For discussions about the role and importance of feelings and emotions in economic contexts, see Loewenstein (2000), Lawler and Thye (1999) and Elster (1998).

${ }^{9}$ According to Robinson and Clore (2002), self-reports are the most common and potentially the best way to measure a person's emotional experience. Alesina et al. (2004), Blanchflower and Oswald (2004), and Ferrer-i-Carbonell (2005) are examples of recent studies of well-being that use self-reports. A recent account of the usefulness of such measures of subjective well-being for policy evaluation is provided by Krueger (2005). For an experimental study using self-reported happiness measures, see Charness and Grosskopf (2001).

${ }^{10}$ The instructions of the experiment can be downloaded from http://www.fee.uva. $\mathrm{nl} /$ creed/pdffiles/instr2compwellbe.pdf.

${ }^{11}$ For the NRC we have complete data for only 52 participants (26 pairs). For the other 20 participants we have all information except the decisions in the first circle test. This was due to computer problems in one of the NRC sessions.

12 This is an abridged version of our obtained results. For a more detailed report and analysis, see the working paper version (Brandts et al., 2008)
}

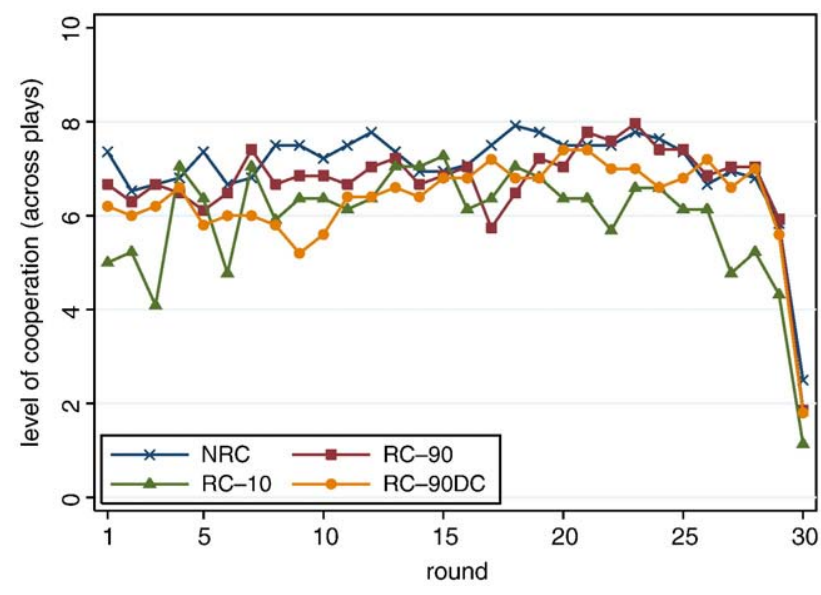

Fig. 2. Development of the level of cooperation (efficiency) in the NRC and the three Rivalry Conditions.

\subsection{Rivalry, efficiency and earnings}

Fig. 2 shows for all four treatments the development of average cooperation rates over actually played games (plays), ignoring decisions of non-chosen $\mathrm{B} / \mathrm{C}$ players in the RCs. This also represents attained efficiency levels in terms of earnings. Recall that 10 is the cooperative choice and 0 the non-cooperative one.

For all four series no large variations across rounds are observed, except for a rather stark end-game effect, common to all conditions. ${ }^{13}$ Result 1 summarizes the comparisons of cooperation levels across conditions as well as earnings across conditions and player types.

\section{Result 1.}

A. There is no significant difference between cooperation levels in the NRC and in the actual plays in each of the three RCs.

B. There is no significant difference in earnings between players in the NRC and A players in the RCs. The same holds for earnings of NRC players and the selected $B$ or $C$ players in each of the RCs.

C. In each of the three RCs the variation (across rounds) in earnings of A players is significantly larger than for players in the NRC.

Part A of Result 1 states that rivalry does not lead to efficiency gains in terms of earnings. For the NRC the cooperation level and dynamics are in keeping with those observed in similar social dilemma games (Andreoni and Miller, 1993; Keser and van Winden, 2000) the average level of cooperation is 7.04 and the standard deviation is 3.39. For RC-90, RC-10, and RC-90DC these figures are 6.71 and 3.06, 5.92 and 3.15, and 6.33 and 3.07, respectively. A KruskalWallis test does not reject equality of the distributions $(p=.1379) .{ }^{14}$ All results remain qualitatively the same when the last two rounds are excluded.

Part B of Result 1 summarizes our finding that the A players in the different RCs cannot utilize their seemingly powerful position to earn more than players in the NRC. When rivalry is absent, average per round earnings of players are 252.2. With rivalry the A players' average earnings per round are 251.6 in RC-90, 257.8 in RC-10 and 249.24 in RC-90DC. A Kruskal-Wallis test does not reject the hypothesis that these earnings are equal in all four treatments

\footnotetext{
13 Such an end-game effect has been found in many other experiments on public goods and social dilemma games. It does not affect our main results.

${ }^{14}$ The Kruskal-Wallis test tests the hypothesis that the four independent samples are drawn from the same population. Where appropriate we use the Mann-Whitney (Wilcoxon signed-ranks) test for independent samples (matched pairs) (Siegel and Castellan, 1988). If not otherwise indicated all test statistics are two-sided (corrected for ties) and the unit of observation is the group (average). In all cases, the alternative-but because of the required normality assumption problematic-t-test gives qualitatively the same results. To save on space we do not report these $t$-test statistics.
} 


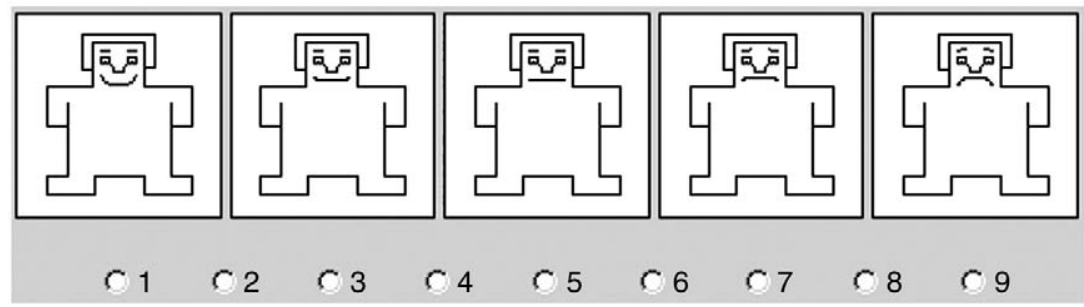

Fig. 3. General measure of subjective well-being.

$(p=.6020)$. Similar comparisons can be made between the NRC earnings and the earnings of actually chosen $\mathrm{B} / \mathrm{C}$ players in the RCs. Interestingly, the average per round earnings of the chosen $\mathrm{B} / \mathrm{C}$ players are in all RCs lower than in the NRC (RC-90: 242.9; RC-10: 216.3; RC-90DC: 235.4), though a Kruskal-Wallis test does not reject the null hypothesis of equality of distributions $(p=.2096)$. Overall, across conditions, differences in earnings are minor and statistically insignificant.

Part $\mathrm{C}$ of Result 1 documents a surprising feature of the interaction under rivalry. In each rivalry treatment the (across rounds) standard deviation of earnings of A players is larger than the (across rounds) standard deviation for players in the NRC (NRC: $65.43(n=72)$; RC90: 89.59 ( $n=27)$; RC-10: $94.95(n=22)$; RC-90DC: $93.08(n=25)$; $p=.0005$, Kruskal-Wallis test). Pair-wise Mann-Whitney tests reject the hypothesis of no difference between NRC and any of the three RCs $(p \leq .0008)$.

A conservative interpretation of Result 1 is that rivalry has at least no positive implications for the allocation of resources. The fact that in many exchange environments the short side obtains a large part of the available surplus is usually considered to have the allocative virtue of attracting resources to that side. This incentive seems not to be present in our environment, if one compares the short side's earnings with that of the NRC. In addition, the fact that the standard deviation of earnings is higher for the A players in any of the RCs in comparison to the NRC shows that being on the short side in the RCs is not such a favorable position as one might expect, intuitively and theoretically. In fact, rivalry leads to more income uncertainty for agents on the short side of the exchange relation, without generating an income increase. ${ }^{15}$

An important question emerging from the above results is, why does the A player not profit from the rivalry between $B$ and $C$ ? An answer may be found in A's partner choice behavior. If A could commit to always changing his interaction partner after the partner having chosen 0 and never switching after the partner having chosen 10 , then he might be able to capitalize on his advantageous position. However, since such a commitment is not possible, uncertainty about A's future behavior may lead the $\mathrm{B} / \mathrm{C}$ players to act opportunistically; i.e., choosing 0 even after successful cooperation in a round. In consonance with this, A may sometimes switch away from a partner who chose 10 . Together, this could lead to a dilution of A's seemingly advantageous situation.

Indeed, in all three rivalry conditions, A's rewarding and punishment behavior is not fully consistent. When both the A player and the chosen partner have made the cooperative choice 10 in a round $t-1$, the A player does frequently not reward the partner, since A either switches partner or stays with the partner but changes to choice 0 . Similarly, if the chosen $\mathrm{B} / \mathrm{C}$ player did not cooperate in a round $t-1$, while A did cooperate, the A player often does not punish this behavior. Another mode of behavior that is likely to increase efficiency and earnings is conditional cooperative behavior (Keser and van

\footnotetext{
${ }^{15}$ The number of times an A player chose the same partner correlated positively with A's earnings in those plays in all three RCs. Similarly, for those B/C players who are chosen more often by the A player, the number of times they are chosen correlates positively with their earnings in those plays in all three RCs. For a more detailed analysis of the relation between stability of relations and earnings see the working paper version (Brandts et al., 2008).
}

Winden, 2000; Fischbacher et al., 2001). We find that compared to the NRC the behavior of the A players in the RCs is less conditionally cooperative, especially regarding cooperative choices. In particular, a choice of 10 by player A in round $t$, following the partner's choice of 10 in round $t-1$, is significantly less likely in the RCs than in the NRC. ${ }^{16}$

These results are consistent with the idea that A players are indeed in a relatively strong position in the RCs. However, since they are not consistently sanctioning defective and rewarding cooperative behavior of their chosen partners they cannot benefit from this structural advantage. In consequence, rivalry does neither increase efficiency nor materially favor the short side of the exchange relation.

\subsection{Subjective well-being after the interaction}

In this and the next section we will discuss subjects' well-being and disposition towards others, respectively. In Section 3.4 we will relate these results with the results from the interactive game.

We use both a general measure and a list of specific emotions to elicit participants' subjective well-being. For measuring general subjective well-being we used Fig. 3. After the interaction phase, subjects were asked to indicate the number below the little figures that best corresponded to their general mood in relation to the facial expressions of the so-called Self-Assessment Manikin. ${ }^{17}$

In the figure, a " 1 " clearly corresponds to the highest level and a " 9 " to the lowest level of subjective well-being. For a better comparison with the emotions scores reported below, we have inverted the score obtained from subjects' decisions in Fig. 3 , so that " 1 " reflects the worst and " 9 " the best mood. Table 2 shows the average values of the general well-being measure for the NRC and the RCs, pooled as well as separately. Result 2 summarizes the results of these comparisons for the NRC, the pooled RCs, and the different player roles.

\section{Result 2.}

A. For players in the NRC general subjective well-being is lower than for A players, higher than for less often chosen $B / C$ players and not different from more often chosen $B / C$ players, in the Rivalry Conditions.

B. In the Rivalry Conditions, for A players general subjective well-being is higher than for both more and less often chosen $B / C$ players.

C. In the Rivalry Conditions, for more often chosen $B / C$ players general subjective well-being is higher than for less often chosen $\mathrm{B} / \mathrm{C}$ players.

Support for this result can be found in Table 2. In the table the superscripts indicate significant differences of pairwise comparisons across player situations and conditions, as explained in the note to the table. For the pooled data all pairwise comparisons are significant (at least at the $2.5 \%$ level, one-sided tests), with the only exception of the difference between players in the NRC and the more often chosen $\mathrm{B} / \mathrm{C}$ players in the RCs. For RC-90 and RC-10 the same pairwise comparisons as for the pooled data appear to be significant. Note, that for these two conditions the levels of our general measure of

\footnotetext{
${ }^{16}$ For a thorough discussion of reciprocity and conditional cooperation please consult Brandts et al. (2008).

17 These figures, developed by Lang (1980), are reprinted from Sonnemans (1991).
} 
Table 2

Averages of general measure of subjective well-being across conditions and roles.

\begin{tabular}{llllll}
\hline \multirow{5}{*}{ Condition-role } \\
\cline { 3 - 6 } & & RC:A & RC:B/C-m.o. & RC:B/C-l.o. & NRC \\
\hline \multirow{2}{*}{ All RC } & General well-being ${ }^{a, b, c, d, f}$ & 7.53 & 6.35 & 3.83 & 6.40 \\
& No. of obs & 74 & $73^{*}$ & 74 & 72 \\
\hline RC-90 & General well-being ${ }^{a, b, c, d, f}$ & 7.85 & 6.09 & 3.50 & \\
RC-10 & General well-being \\
RC-90DC & General well-being ${ }^{b, c, f}, f$ & 7.72 & 5.81 & 3.73 & \\
& No. of obs & 22 & 7.08 & 4.28 & \\
\hline
\end{tabular}

Note: Scores for well-being range from 1 (feel "very bad") to 9 (feel "very good"). "m.o." ("l.o.") stands for "more (less) often chosen".

${ }^{a}$ Significant difference between RC:A and RC:B/C-m.o.

${ }^{b}$ Significant difference between RC:A and RC:B/C-l.o.

${ }^{c}$ Significant difference between RC:B/C-m.o. and RC:B/C-l.o.

${ }^{d}$ Significant difference between RC:A and NRC.

${ }^{e}$ Significant difference between RC:B/C-m.o. and NRC.

${ }^{f_{S}}$ Significant difference between RC:BC-l.o. and NRC; all significances at least at $2.5 \%$ level, Mann-Whitney rank sum tests, one-sided.

${ }^{*} n=21$ in RC-10 due to one missing observation.

subjective well-being are different between all three player situations. Being on the short or long side does make a difference for subjective well-being, independent of the earnings obtained outside the relation. Those on the long side feel significantly worse than players on the short side. Moreover, being mostly excluded on the long side has an additional negative impact on subjective well-being. Observe also that, in comparison to the NRC, the reported scores of our general measure in the RC-90 and RC-10 conditions are at a higher, a lower and a similar level, depending on the position of the players. Hence, rivalry has led to an inequality in subjective well-being without generating material efficiency gains. For the RC-90DC the results are slightly different as the comparison between RC-A and both RC-B/C m. o. and NRC are not significant, while all other differences stay significant also in this condition.

Next to the general measure of subjective well-being subjects also reported the experienced intensity of a number of specific emotions. As expected, negative emotions (sadness, envy, anger, irritation, contempt) are negatively correlated with general well-being while positive emotions (happiness, pride, joy, relief) correlate positively with this measure $(p<.025$ for all mentioned emotions, using the pooled data from the Rivalry Conditions). These results support the interpretation that our general measure indeed indicates how people feel and demonstrates the close relation between subjective well-being in a more general sense and the intensity of experienced specific emotions.

\subsection{Disposition towards others before and after the interaction}

Table 3 presents the averages and standard deviations of the angles observed in the circle tests of parts 1 and 3, for the NRC and the RCs, pooled as well as separately. We refer to the chosen angles in part 1 (part 3) as initial (final) angles. For the RCs we distinguish between player types and, for the $\mathrm{B} / \mathrm{C}$ players, between more often (m.o.) and less often (l.o.) chosen ones.

In line with earlier studies using social value orientation tests in economic experiments (Offerman et al., 1996), we find that many people are initially positively inclined towards anonymous others. Unsurprisingly, initial angles do not significantly differ between treatments. On average the angles are $15.37^{\circ}$ in the NRC and 14.01, 15.75 , and 18.54 in the three RCs (cf. left part of Table 3$).{ }^{18}$ A KruskalWallis test does not reject the hypothesis that the angles come from the same population $(p=.3937)$. There is also no statistically significant difference in initial angles between those subjects who-

\footnotetext{
${ }^{18}$ An angle of $15^{\circ}$ implies a transfer of 259 points to the other person, whereas 966 points are kept.
}

without knowing it beforehand-became an A player and those who became a B/C player in the three RCs ( $p \geq .6333$, Mann-Whitney test).

Next consider the final angles shown on the right part of Table 3. These angles were measured after the interaction phase and, hence, are payoff relevant expressions of post-interaction disposition towards others. Our main interest is in whether and how rivalry and experience during the interaction phase affect people's disposition towards others. We, therefore, focus on changes relative to the initial angles. With the notable exception of A players behavior towards more often chosen $\mathrm{B} / \mathrm{C}$ players, we observe a general tendency for angles to decrease from the pre-game to the postgame situation, in all conditions. Such a general 'decay' is in keeping with the results of van Dijk et al. (2002). Importantly, however, the observed changes clearly differ between the NRC and the RCs as well as between player roles. The pattern of these differences is summarized in the following result. ${ }^{19}$

Result 3. Compared to the disposition towards others before the interactive game:

A. In the NRC, players' disposition towards their partners do not significantly change, whereas it exhibits a significant decrease towards third parties.

B. In the RCs, A players' disposition towards the more often chosen partner does not significantly change, but significantly decreases towards the less often chosen partner.

C. In the RCs, the more often chosen $\mathrm{B} / \mathrm{C}$ players' disposition towards A players and less often chosen $B / C$ players significantly decreases.

D. In the RCs, the less often chosen $B / C$ players' disposition towards $A$ players and more often chosen $\mathrm{B} / \mathrm{C}$ players significantly decreases.

In the NRC, the hypothesis of equality of distributions of initial angles and final angles towards the partner is not rejected $(p=.1775)$. In contrast, when comparing initial angles with final angles towards the third party the null hypothesis of equality is rejected $(p=.0132)$.

In the RCs we need to distinguish between A players and more and less often chosen $\mathrm{B} / \mathrm{C}$ players. In the following we present the test results for the pooled data of all RCs and mention the results for an individual Rivalry Condition only if it differs from the pooled pattern. Part B of the above result captures the A players' changes in dispositions towards interaction partners. Compared to their initial disposition, A players do not significantly modify their disposition towards the more often chosen partner $(p=.7734)$. In stark contrast, concerning the less often chosen partner the final angles decrease significantly $(p=.0005)$. For RC-90DC this decrease is large in absolute terms, but statistically not significant $(p=.1523)$.

For the more often chosen $\mathrm{B} / \mathrm{C}$ players (part $\mathrm{C}$ ) equality of distributions of initial angles and final angles towards A players is rejected $(p=.0009)$. However, for RC-90 the decrease is insignificant $(p=.1650)$ and only marginally significant for RC-10 $(p=.0593)$, indicating that the result is mostly driven by RC-90DC. When comparing the initial angle of $\mathrm{B} / \mathrm{C}$ players with the final angle regarding the less often chosen $\mathrm{B} / \mathrm{C}$ fellow equality of distributions is rejected $(p=.0019)$. On the individual RC level the differences are at best only marginally significant, though (RC-90: $p=.0552$; RC-10: $p=.0856$ ).

For the less often chosen $\mathrm{B} / \mathrm{C}$ players (part D) equality of distributions of initial and the final angles regarding the A-player is rejected $(p<.0001)$. Note, that the negative angles (average: -2.97 ) implies that less often chosen $\mathrm{B} / \mathrm{C}$ players gave up money in order to reduce the earnings of A-players. When comparing the initial angle with the final angle towards more often chosen $B / C$ fellow players we also observe a significant decrease $(p=.0018)$. Among the individual

\footnotetext{
${ }^{19}$ To save on space, for the RCs the result refers to the pooled data. The few differences between the RCs are discussed after the result. All $p$-values reported for the statistical support of this result come from Wilcoxon signed-ranks tests.
} 
Table 3

Disposition towards others - average angles in the circle tests.

\begin{tabular}{|c|c|c|c|c|c|c|c|c|c|c|c|c|c|}
\hline & \multicolumn{5}{|c|}{ Initial angle of } & \multicolumn{8}{|c|}{ Final angle of } \\
\hline & All & A & B/C (all) & B/C-m.o. & B/C-l.o. & $\begin{array}{l}\text { All } \\
\text { towards } \\
\text { partner }\end{array}$ & $\begin{array}{l}\text { All towards } \\
\text { third party }\end{array}$ & $\begin{array}{l}\text { A towards } \\
\text { B/C-m.o. }\end{array}$ & $\begin{array}{l}\text { A towards } \\
\text { B/C-l.o. }\end{array}$ & $\begin{array}{l}\text { B/C-m.o. } \\
\text { towards A }\end{array}$ & $\begin{array}{l}\text { B/C-m.o. } \\
\text { towards } \\
\text { B/C-l.o. }\end{array}$ & $\begin{array}{l}\mathrm{B} / \mathrm{C}-\mathrm{l} . \mathrm{o} \text {. } \\
\text { towards A }\end{array}$ & $\begin{array}{l}\text { B/C-l.o. } \\
\text { towards } \\
\text { B/C-m.o. }\end{array}$ \\
\hline NRC & $\begin{array}{l}15.37 \\
(18.40) \\
{[n=52]^{a}}\end{array}$ & & & & & $\begin{array}{l}10.67 \\
(24.17) \\
{[n=52]^{c}}\end{array}$ & $\begin{array}{l}9.68 \\
(15.49) \\
{[n=52]^{c}}\end{array}$ & & & & & & \\
\hline All RC & $\begin{array}{l}16.07 \\
(21.84) \\
{[n=221]^{b}}\end{array}$ & $\begin{array}{l}16.02 \\
(18.73) \\
{[n=73]^{b}}\end{array}$ & $\begin{array}{l}16.10 \\
(23.28) \\
{[n=148]}\end{array}$ & $\begin{array}{l}18.38 \\
(18.85) \\
{[n=74]}\end{array}$ & $\begin{array}{l}13.81 \\
(26.66) \\
{[n=74]}\end{array}$ & & & $\begin{array}{l}16.92 \\
(19.64) \\
{[n=73]^{d}}\end{array}$ & $\begin{array}{l}10.17 \\
(18.71) \\
{[n=73]^{d}}\end{array}$ & $\begin{array}{l}9.98 \\
(20.39) \\
{[n=74]}\end{array}$ & $\begin{array}{l}11.74 \\
(18.16) \\
{[n=74]}\end{array}$ & $\begin{array}{l}-2.97 \\
(27.48) \\
{[n=74]}\end{array}$ & $\begin{array}{l}6.38 \\
(16.51) \\
{[n=74]}\end{array}$ \\
\hline RC-90 & $\begin{array}{l}14.01 \\
(26.03) \\
{[n=80]^{b}}\end{array}$ & $\begin{array}{l}14.90 \\
(19.43) \\
{[n=26]^{b}}\end{array}$ & $\begin{array}{l}13.58 \\
(28.83) \\
{[n=54]}\end{array}$ & $\begin{array}{l}19.20 \\
(21.99) \\
{[n=27]}\end{array}$ & $\begin{array}{l}7.96 \\
(33.81) \\
{[n=27]}\end{array}$ & & & $\begin{array}{l}14.54 \\
(20.14) \\
{[n=26]^{d}}\end{array}$ & $\begin{array}{l}6.93 \\
(14.40) \\
{[n=26]^{d}}\end{array}$ & $\begin{array}{l}12.49 \\
(19.24) \\
{[n=27]}\end{array}$ & $\begin{array}{l}12.59 \\
(16.79) \\
{[n=27]}\end{array}$ & $\begin{array}{l}-4.19 \\
(27.03) \\
{[n=27]}\end{array}$ & $\begin{array}{l}5.95 \\
(13.61) \\
{[n=27]}\end{array}$ \\
\hline $\mathrm{RC}-10$ & $\begin{array}{l}15.75 \\
(19.48) \\
{[n=66]}\end{array}$ & $\begin{array}{l}15.60 \\
(20.17) \\
{[n=22]}\end{array}$ & $\begin{array}{l}15.84 \\
(19.36) \\
{[n=44]}\end{array}$ & $\begin{array}{l}18.75 \\
(17.94) \\
{[n=22]}\end{array}$ & $\begin{array}{l}12.93 \\
(20.48) \\
{[n=22]}\end{array}$ & & & $\begin{array}{l}16.28 \\
(18.77) \\
{[n=22]}\end{array}$ & $\begin{array}{l}12.36 \\
(17.94) \\
{[n=22]}\end{array}$ & $\begin{array}{l}10.80 \\
(19.75) \\
{[n=22]}\end{array}$ & $\begin{array}{l}11.13 \\
(16.49) \\
{[n=22]}\end{array}$ & $\begin{array}{l}-2.84 \\
(20.45) \\
{[n=22]}\end{array}$ & $\begin{array}{l}7.69 \\
(13.72) \\
{[n=22]}\end{array}$ \\
\hline RC-90DC & $\begin{array}{l}18.54 \\
(18.73) \\
{[n=75]}\end{array}$ & $\begin{array}{l}17.56 \\
(17.29) \\
{[n=25]}\end{array}$ & $\begin{array}{l}19.03 \\
(19.56) \\
{[n=50]}\end{array}$ & $\begin{array}{l}17.18 \\
(16.50) \\
{[n=25]}\end{array}$ & $\begin{array}{l}20.89 \\
(21.57) \\
{[n=25]}\end{array}$ & & & $\begin{array}{l}19.97 \\
(20.25) \\
{[n=25]}\end{array}$ & $\begin{array}{l}11.60 \\
(23.11) \\
{[n=25]}\end{array}$ & $\begin{array}{l}6.55 \\
(22.41) \\
{[n=25]}\end{array}$ & $\begin{array}{l}11.36 \\
(21.42) \\
{[n=25]}\end{array}$ & $\begin{array}{l}-1.77 \\
(33.70) \\
{[n=25]}\end{array}$ & $\begin{array}{l}5.68 \\
(21.50) \\
{[n=25]}\end{array}$ \\
\hline
\end{tabular}

Note: "m.o." ("l.o.") stands for "more (less) often chosen.

a Observations of one session are missing due to technical problems.

${ }^{b}$ One missing observation in RC-90.

${ }^{c}$ Without observations that correspond to the missing observations in the first circle test (see ${ }^{a}$ ).

${ }^{d}$ Without observation that corresponds to the missing observation in the first circle test $\left(\right.$ see $\left.^{b}\right)$; in cases where both B/C players are chosen exactly 15 times the average angles of the two players is used when calculating the angles for the "more often" and "less often" chosen players. Standard deviations in parentheses.

RCs the observed decrease is statistically not significant in RC-90 $(p=.4178)$.

A general insight from the findings of this and the previous section is that subjective well-being and dispositions towards others are strongly influenced by the interaction institution and the role in which a person participates in the interactive game. In particular, being on the long side of the exchange situation has a strong negative effect on players' subjective well-being and their disposition towards other players, especially those on the short side. ${ }^{20}$

\subsection{The relation of interaction experience, post-interaction well-being and disposition towards others}

In this section we briefly report on the results of a regression analysis that studies how well-being, experienced emotions and interaction success are related to the post-game disposition towards others. We presume the following relations: (i) well-being and emotions are influenced by experience in the game, that is, by both, the interaction success in monetary terms and the position a player is in; (ii) the disposition towards others after the interaction is affected by interaction success but also by emotional factors, which allows for an indirect-via interaction success-as well as direct effect of emotions on the disposition towards others. ${ }^{21}$ In the following we concentrate on the NRC and the pooled data of all three Rivalry Conditions.

For general well-being and each specific emotion we ran separate OLS regressions with interaction success, measured as sum of earnings across actual plays, as explanatory variable. For subjects in NRC general well-being, the positive emotions happiness, pride, and joy

\footnotetext{
${ }^{20}$ We do not study the potentially important issue of gender effects. For an interesting study of the relation between competition and gender, see Niederle and Vesterlund (2007).

${ }^{21}$ As a referee pointed out, we cannot completely rule out the possibility that postgame dispositions towards others are to some extent ex-post rationalizations of the earlier elicited emotions. However, our results are not invariant between the NRC and the Rivalry Conditions (see below), indicating that ex-post rationalizations are unlikely to be an important explanation of the relations we find. Recall also that choices in the circle test are incentivized.
}

and the negative emotions sadness, envy, anger, and irritation are strongly significantly related to interaction success, with the expected signs $(p<.01)$. In addition, surprise shows a significantly negative sign $(p<.01)$. These results indicate that the emotional state of NRC players is strongly correlated with their earnings success in the incomplete contract game.

The picture turns out to be different in the Rivalry Conditions. For the A players general well-being is significantly positively related to interaction success in plays with the more often chosen $\mathrm{B} / \mathrm{C}$ player $(p<.01)$ but marginally negatively related to interaction success with the less often chosen player $(p<.1)$. Of the specific emotions the positive emotions happiness, relief, and joy are positively and the negative emotion anger is negatively correlated with interaction success in plays with the more often chosen $\mathrm{B} / \mathrm{C}$ player $(p<.01)$. Interaction success in plays with the less often chosen $B / C$ player has no significant effect on any of the specific emotions. Hence, for players on the short side in the RCs interaction success shows a weaker relation with the emotional state and general subjective well-being.

While for $\mathrm{B} / \mathrm{C}$ players interaction success and general well-being are positively correlated and similar for more and less often chosen ones ( $p<.01$ and $p<.05$, respectively), the effect for the specific emotions differs strongly. More often chosen $B / C$ players' positive emotions (happiness, pride, relief, joy) and negative emotions (sadness, envy, anger, irritation, contempt) are significantly $(p<.05)$ related to interaction success, with the expected sign. In contrast, for the less often chosen $\mathrm{B} / \mathrm{C}$ players the negative emotions sadness and anger indicate a significantly negative correlation with interaction success $(p<.05)$, while all other specific emotions seem unrelated to this experience.

In the following, we explore how emotions and interaction success relate to the disposition towards others. Due to the substantial correlations among the experienced emotions, we performed a factor analysis to identify the main dimensions for a regression analysis. It turns out that for all four player roles only three factors had eigenvalues larger than 1 , and together accounted for more than $60 \%$ of the variance of the thirteen emotion items. For the first factor the factor loadings were high for the negative emotions anger, sadness, irritation, and contempt; for the second factor they were high for the positive emotions joy, happiness, and pride; for the third factor they were high for the emotions guilt, shame, and fear. We call these 
Table 4

Determinants of post-game disposition towards others - in No Rivalry and Rivalry Conditions.

\begin{tabular}{|c|c|c|c|c|c|c|c|c|}
\hline & \multicolumn{2}{|c|}{$\begin{array}{l}\text { A/B players in NRC } \\
\text { towards }\end{array}$} & \multicolumn{2}{|c|}{$\begin{array}{l}\text { A players in the RC's } \\
\text { towards }\end{array}$} & \multicolumn{2}{|c|}{$\begin{array}{l}\mathrm{B} / \mathrm{C} \text {-m.o. in the RC's } \\
\text { towards }\end{array}$} & \multicolumn{2}{|c|}{$\begin{array}{l}\mathrm{B} / \mathrm{C} \text {-l.o. in the } \mathrm{RC} \text { 's } \\
\text { towards }\end{array}$} \\
\hline & $\mathrm{B} / \mathrm{A}$ & 3rd party & B/C-m.o. & B/C-1.o. & A & B/C-l.o. & A & B/C-m.o. \\
\hline Initial disposition & $\begin{array}{l}.3158 \\
(.065)\end{array}$ & $\begin{array}{l}.3654 * * \\
(.001)\end{array}$ & $\begin{array}{l}.2990^{*} \\
(.023)\end{array}$ & $\begin{array}{l}.2491^{*} \\
(.038)\end{array}$ & $\begin{array}{l}.3975 * * \\
(.000)\end{array}$ & $\begin{array}{l}.5550 * * \\
(.000)\end{array}$ & $\begin{array}{l}.5171 * * \\
(.000)\end{array}$ & $\begin{array}{l}.2277 * * \\
(.001)\end{array}$ \\
\hline Interaction success & $\begin{array}{l}-.0326 \\
(.616)\end{array}$ & & $\begin{array}{l}.0004 \\
(.765)\end{array}$ & $\begin{array}{l}.0014 \\
(.369)\end{array}$ & $\begin{array}{l}.0017 \\
(.156)\end{array}$ & & $\begin{array}{l}.0012 \\
(.625)\end{array}$ & \\
\hline Anger factor & $\begin{array}{l}-7.404^{*} \\
(.016)\end{array}$ & $\begin{array}{l}-1.117 \\
(.508)\end{array}$ & $\begin{array}{l}1.526 \\
(.515)\end{array}$ & $\begin{array}{l}2.701 \\
(.195)\end{array}$ & $\begin{array}{l}-5.115^{*} \\
(.045)\end{array}$ & $\begin{array}{l}.5921 \\
(.731)\end{array}$ & $\begin{array}{l}-8.338^{* *} \\
(.002)\end{array}$ & $\begin{array}{l}.2199 \\
(.903)\end{array}$ \\
\hline Joy factor & $\begin{array}{l}4.015 \\
(.226)\end{array}$ & $\begin{array}{l}2.825 \\
(.136)\end{array}$ & $\begin{array}{l}1.865 \\
(.433)\end{array}$ & $\begin{array}{l}1.387 \\
(.514)\end{array}$ & $\begin{array}{l}-1.317 \\
(.583)\end{array}$ & $\begin{array}{l}.3572 \\
(.835)\end{array}$ & $\begin{array}{l}1.904 \\
(.488)\end{array}$ & $\begin{array}{l}1.990 \\
(.284)\end{array}$ \\
\hline Guilt factor & $\begin{array}{l}6.290 * \\
(.027)\end{array}$ & $\begin{array}{l}1.903 \\
(.286)\end{array}$ & $\begin{array}{l}2.335 \\
(.334)\end{array}$ & $\begin{array}{l}5.319^{*} \\
(.017)\end{array}$ & $\begin{array}{l}1.207 \\
(.562)\end{array}$ & $\begin{array}{l}-2.875 \\
(.096)\end{array}$ & $\begin{array}{l}4.802 \\
(.072)\end{array}$ & $\begin{array}{l}-.6343 \\
(.728)\end{array}$ \\
\hline Constant & $\begin{array}{l}13.84 \\
(.410)\end{array}$ & $\begin{array}{l}4.056 \\
(.089)\end{array}$ & $\begin{array}{l}9.941 \\
(.209)\end{array}$ & $\begin{array}{l}3.746 \\
(.325)\end{array}$ & $\begin{array}{l}-6.899 \\
(.335)\end{array}$ & $\begin{array}{l}1.287 \\
(.589)\end{array}$ & $\begin{array}{l}-12.10^{*} \\
(.017)\end{array}$ & $\begin{array}{l}3.233 \\
(.115)\end{array}$ \\
\hline$R^{2}$ & .3194 & .3478 & .1217 & .1981 & .2872 & .3719 & .3809 & .1733 \\
\hline$N$ & 52 & 52 & 73 & 73 & 73 & 73 & 74 & 74 \\
\hline
\end{tabular}

Note: Seemingly unrelated regressions.

** significant at the $1 \%$ level.

* significant at the $5 \%$ level; $p$-values (2-sided) between parentheses.

three factors the anger factor, the joy factor and the guilt factor, for obvious reasons. $^{22}$

We examined models of seemingly unrelated regressions for the NRC and the pooled data of the RCs and all player roles. In the regression models the independent variable is the disposition towards others after the game (final angle), and the explanatory variables are the initial disposition towards others (initial angle), the interaction success (sum of earnings over plays), and the three emotion factors just described.

Table 4 presents the regression results. ${ }^{23}$ In the NRC we need to distinguish between changes of disposition towards the partner in the interactive game and the randomly chosen third player. In the table, the left column pertains to the partner in the interactive game and the right column relates to the third player. The results show that in the NRC interaction success has no significant effect. In contrast, the disposition towards the interaction partner is significantly negatively affected by the anger factor and significantly positively affected by the guilt factor. The disposition towards the third party is unaffected by emotional factors, indicating that the emotions are directed towards the partner in the interactive game. Together with the result that the emotions of players in the NRC are correlated with interaction success the overall picture is consistent with the idea that interaction success triggers emotional responses, which in turn, determine people's postinteraction disposition towards their interaction partner. Note, that the effect of earnings on the final disposition towards the interaction partner is only indirect and mediated by the emotions. ${ }^{24}$

The next two columns in Table 4 show regression results for the $\mathrm{A}$ players in the RCs. Now the left column relates to the more often chosen and the right column to the less often chosen $\mathrm{B} / \mathrm{C}$ player. The initial disposition towards others has a significantly positive effect

\footnotetext{
22 The criteria we use for selecting the factors are two of the most widely used conventions. There were some minor variations of the factor loadings across player types. The complete list of factor loadings can be obtained from the authors upon request.

${ }^{23}$ For each condition and player position, we have run three nested regression models, one with only interaction success as independent variable, one with only the emotion factors as independent variables, and a third with both types of variables included, next to the initial angle and a constant. Likelihood ratio tests indicate that the specification presented here performs best. The working paper version (Brandts et al., 2008) discusses all regressions in more detail.

${ }^{24}$ Such a mediator effect is well known in social psychology research (Baron and Kenny, 1986).
}

whereas interaction success has no significant effect. The guilt factor is significantly positively related with the disposition towards the less often chosen $\mathrm{B} / \mathrm{C}$ players. This indicates that feelings of guilt, shame, and fear increased the disposition of the A players towards those $\mathrm{B} / \mathrm{C}$ players they have frequently excluded during the game. Since the emotions of A players in the RCs are not affected by interaction success with the less often chosen $\mathrm{B} / \mathrm{C}$ player, their post-game disposition is neither directly nor indirectly (via the emotions) influenced by interaction success. Next to the initial disposition, only the emotion factor guilt is an important direct determinant for the final disposition towards the interaction partner on the long side of the exchange relation.

The right side of Table 4 shows the results for the more often chosen $B / C$ players and for the less often chosen ones. Here the left columns refer to the A player and the right columns to the other $\mathrm{B} / \mathrm{C}$ player. We discuss the regression results for both kinds of $B / C$ players together. Next to the initial disposition, the post-game disposition towards the A players is strongly and significantly negatively influenced by the anger factor, indicating that negative feelings strongly decrease their kindness towards the player on the short side of the interaction, but not towards their co-players on the long side. For the more often chosen $\mathrm{B} / \mathrm{C}$ player we identify a pronounced mediator effect of the anger factor. Interaction success influences the disposition of more often chosen $\mathrm{B} / \mathrm{C}$ players towards A players only indirectly via the emotions constituting this factor (that is, it loses its significance if emotions are added to the regression). For the less often chosen $\mathrm{B} / \mathrm{C}$ players we neither find a significant direct relation between the emotions entering the anger factor and interaction success nor is there a significant direct effect of interaction success on the disposition towards A players. Together, this shows that the postgame disposition of more often excluded players on the long side is directly negatively affected by their negative emotional feelings. ${ }^{25}$ The next result summarizes our findings in this section.

\footnotetext{
${ }^{25}$ One might speculate that the desire to reduce earnings inequalities drives the final disposition of the less often chosen $\mathrm{B} / \mathrm{C}$ players towards their richer A players. To test this we have also run regressions where we included the total earnings across plays (as well as across rounds) of the less often chosen $\mathrm{B} / \mathrm{C}$ player relative to the earnings of the A player as a measure of interaction success. None of these alternative measures of interaction success is significant, neither when used separately nor when used jointly. In all alternative specifications the anger factor stays significant at the $1 \%$ level. Hence, for our results the explanation that less often chosen $\mathrm{B} / \mathrm{C}$ players punish $\mathrm{A}$ players because of earnings inequalities has no bite.
} 
Result 4. In all conditions and for all player roles the final disposition towards others is positively related to the initial disposition. In addition, the following holds for the final disposition towards others:

A. For players in the NRC it is related only indirectly to interaction success, mediated by the emotion factors of anger and guilt.

B. For the A players in the RCs it is neither directly nor indirectly related to interaction success, but towards the less often chosen $\mathrm{B} / \mathrm{C}$ player it is positively related to the guilt factor.

C. For the more often chosen B/C players in the RCs the final disposition towards the A players is indirectly related to interaction success via the anger emotion factor.

D. For the less often chosen $\mathrm{B} / \mathrm{C}$ players in the RCs the final disposition towards the A players is neither directly nor indirectly related to interaction success but is strongly negatively influenced by the emotion factor of anger.

From Section 3.2 we know that the general subjective well-being of players strongly depends on the competitiveness of the institution players are put in as well as their position in the competitive environment. We have also seen that interaction success, measured by earnings, is insufficient to explain these differences. The above result shows that emotional states rather than pure monetary outcomes are related to behavior after the interaction in the game. In summary, mediated by the emotional state, the experience with rivalry as such and the role people are immersed in are important determinants of the disposition towards others, while interaction success plays only an indirect and partial role.

\section{Final comments}

We find that rivalry matters, but in a very different way than is typically assumed in economics. In our experimental exchange environment without complete contracts rivalry does neither enhance efficiency nor does it increase the earnings of the short side of the exchange relation. It does have positive effects on the subjective well-being of people on the short side. However, rivalry has hidden costs that are related to people's emotional reaction to lack of control and the possibility of exclusion from trade. Being exposed to a competitive environment lowers subjective well-being and triggers negative emotions for those on the long side. Rivalry has also adverse effects on the behavioral disposition towards those interacted with. Experience with rivalry appears to decrease the subsequent willingness to help. This effect is strongest for those who are frequently excluded. Importantly, these effects cannot be explained by earnings differences generated during the interaction alone, but are strongly related to experienced emotions.

One can speculate about potential longer term effects of experienced rivalry. In our study, rivalry leads to a deterioration of the social relations between interaction partners and considerably depresses the subjective well-being of those on the long side of exchange who are often excluded from interaction. These facts may lead to the obstruction of future cooperation. Note, that the formation of mostly stable bilateral relations cannot completely solve this problem, because in most competitive situations bilateral relations necessarily imply the exclusion of some parties from materially beneficial interactions. Additionally, in a dynamic society established bilateral relations will not hold forever. When interactions between new partners have to take place, they may bring together parties with a negative disposition towards others. In addition, the subjective wellbeing of those parties that have previously been frequently excluded from the interaction may be low. This in turn may feed back to individuals' behavior with possibly adverse effects on efficiency. In line with this reasoning, Okada and Riedl (2005) find that in the related context of coalitional bargaining exclusion frequently takes place leading to unfair and inefficient outcomes.
Our study connects with recent papers providing new perspectives on rivalry. Brown et al. (2004) examine the emergence of fixed longterm partnerships between workers and firms under incomplete contracting. They find that-due to contract incompleteness-the market place resembles a collection of bilateral trading islands rather than a competitive market. In a related vein, Kirchsteiger et al. (2005) study how market institutions endogenously emerge.

In a more general sense, our evidence is in favor of the view that socio-psychological influences and those aspects of human interaction mostly related to material welfare and pecuniary incentives can (and should) not always be kept apart or disentangled. Granovetter (1985) refers to this as the embeddedness of economic activity in social relations. Interpersonal rivalry can hurt the social relations which are necessary for the successful pursuit of material wealth. Our results add to, but are different from, the criticism of market economies put forward by Lane $(1991,2000)$. His point is, that in market economies people are drawn into striving too much for material things at the expense of companionship. Our contribution consists in providing evidence of the social and affective costs of rivalry as such. In broad terms our results here relate to the work of Bohnet et al. (2001), Fehr and Gächter (2002) and Bénabou and Tirole (2003).

Clearly, our research does not cast light on every facet of rivalry, as for example, the relation between competition and the efficient allocation of resources. Other settings and institutional environments should be investigated. An interesting paper in this respect is Falk et al. (2008) who show that the successful use of tournaments by firms depends on institutional details like the possibility of sabotage.

\section{Acknowledgement}

The authors thank two anonymous referees, Jim Andreoni, Armin Falk, Ernst Fehr, Christiane Schwieren, Alaž Ule and the participants of seminars and conferences in Amsterdam, Barcelona, Erfurt, Munich, and Zürich for valuable comments, David Rodriguez for excellent research assistance, Karin Breen for the translation of the experimental instructions and Jos Theelen for writing the software for the experiment. Financial support by the European Union through the TMR research network ENDEAR (FMRX-CT98-0238) and ENABLE (MRTM-CT2003-505223) as well as by the Spanish Ministry of Science and Innovation and Consolider Ingenio 2010 (CSD 2006-00016) is gratefully acknowledged.

\section{References}

Akerlof, George, 1970. The market for lemons: quality uncertainty and the market mechanism. Quarterly Journal of Economics 84, 488-500.

Alesina, Alberto, Di Tella, Rafael, MacCulloch, Robert, 2004. Inequality and happiness: are Europeans and Americans different. Journal of Public Economics 88, 2009-2042.

Andreoni, James, Miller, John H., 1993. Rational cooperation in the finitely prisoner's dilemma: experimental evidence. The Economic Journal 103, 570-587.

Baron, Reuben M., Kenny, David A., 1986. The moderator-mediator variable distinction in social psychological research: conceptual, strategic, and statistical considerations. Journal of Personality and Social Psychology 51, 1173-1182.

Barrett-Howard, Edith, Tyler, Tom R., 1986. Procedural justice as a criterion in allocation decisions. Journal of Personality and Social Psychology 50, 296-304.

Bénabou, Roland, Tirole, Jean, 2003. Intrinsic and extrinsic motivation. Review of Economic Studies 70, 489-520.

Bies, Robert, Tripp, Thomas, Neale, Margaret, 1993. Procedural fairness and profit seeking: the perceived legitimacy of market exploitation. Journal of Behavioral Decision Making 6, 243-256.

Blanchflower, David G., Oswald, Andrew J., 2004. Well-being over time in Britain and the USA. Journal of Public Economics 88, 1359-1386.

Bohnet, Iris, Frey, Bruno, Huck, Steffen, 2001. More order with less law: on contract enforcement, trust and crowding. American Political Science Review 95, 131-144.

Bolton, Gary, Ockenfels, Axel, 2000. ERC: a theory of equity, reciprocity, and rivalry American Economic Review 90, 166-193.

Bolton, Gary, Brandts, Jordi, Ockenfels, Axel, 2005. Fair procedures. evidence from games involving lotteries. The Economic Journal 115, 1054-1076.

Bosman, Ronald, van Winden, Frans, 2002. Emotional hazard in a power-to-take game experiment. The Economic Journal 112, 147-169. 
Bowles, Samuel, 1998. Endogenous preferences: the cultural consequences of markets and other economic institutions. Journal of Economic Literature 36, 75-111.

Brandts, Jordi, Charness, Gary, 2004. Do labor market conditions affect gift exchange? Some experimental evidence. The Economic Journal 114, 584-708.

Brandts, Jordi, Riedl, Arno, van Winden, Frans, 2008. On competition and well-being. an experimental investigation into rivalry, social disposition, and subjective wellbeing. Working paper. Maastricht University.

Brown, Martin, Falk, Armin, Fehr, Ernst, 2004. Relational contracts and the nature of market interactions. Econometrica 72, 747-780.

Charness, Gary, Grosskopf, Brit, 2001. Relative payoffs and happiness: an experimental study. Journal of Economic Behavior and Organization 45, 301-328.

Charness, Gary, Levine, David, 2000. When are layoffs acceptable? Evidence from quasi-experiment. Industrial Labor Relations Review 53, 381-400.

Charness, Gary, Rabin, Matthew, 2002. Understanding social preferences with simple tests. Quarterly Journal of Economics 117, 817-869.

Davis, Douglas D., Holt, Charles A., 1994. Equilibrium cooperation in three-person choice-of-partner games. Games and Economic Behavior 7, 39-53.

van Dijk, Frans, Sonnemans, Joep, van Winden, Frans, 2002. Social ties in a public goods experiment. Journal of Public Economics 85, 275-299.

van Dijk, Frans, van Winden, Frans, 1997. Dynamics of social ties and local public good provision. Journal of Public Economics 64, 323-341.

Dufwenberg, Martin, Kirchsteiger, Georg, 2004. A theory of sequential reciprocity. Games and Economic Behavior 47, 268-298.

Elster, Jon, 1998. Emotions and economic theory. The Economic Journal 36 (2), 47-74

Falk, Armin, Fischbacher, Urs, 2006. A theory of reciprocity. Games and Economic Behavior 54, 293-315.

Falk, Armin, Fehr, Ernst, Huffman, David, 2008. The power and limits of tournament incentives. Working Paper. University of Bonn.

Fehr, Ernst, Falk, Armin, 1999. Wage rigidity in a competitive incomplete contract market. Journal of Political Economy 107, 106-134.

Fehr, Ernst, Gächter, Simon, 2002. Do incentive contracts undermine voluntary cooperation? Working Paper No. 34. University of Zurich.

Fehr, Ernst, Schmidt, Klaus, 1999. A theory of fairness, rivalry, and cooperation. Quarterly Journal of Economics 114, 817-868

Fehr, Ernst, Kirchsteiger, Georg, Riedl, Arno, 1993. Does fairness prevent market clearing? An experimental investigation. Quarterly Journal of Economics 108 (2), 437-460.

Fehr, Ernst, Gächter, Simon, Kirchsteiger, Georg, 1997. Reciprocity as a contract enforcement device. Econometrica 65, 833-860.

Fehr, Ernst, Kirchsteiger, Georg, Riedl, Arno, 1998. Gift exchange and reciprocity in competitive experimental markets. European Economic Review 42, 1-34.

Ferrer-i-Carbonell, 2005. Income and well-being: an empirical analysis of the comparison income effect. Journal of Public Economics 89, 997-1019.

Fischbacher, Urs, Gächter, Simon, Fehr, Ernst, 2001. Are people conditionally cooperative? Evidence from a public goods experiment. Economics Letters 713 , 397-404.

Frey, Bruno, Stutzer, Alois, 2002. What economists can learn from happiness research. Journal of Economic Literature XL, 402-435.

Granovetter, Mark, 1985. Economic action and social structure: the problem of embeddedness. American Journal of Sociology 91, 481-510.

Hannan, R. Lynn, Kagel, John, Moser, Donald, 2002. Partial gift exchange in experimental labor markets: impact of subject population differences, productivity differences and effort request on behavior. Journal of Labor Economics 20,923-951.

Kahneman, Daniel, Knetsch, Jack, Thaler, Richard, 1986. Fairness as a constraint on profitseeking: entitlements in the market. American Economic Review 76, 728-741.
Kahneman, Daniel, Wakker, Peter P. Sarin, Rakesh, 1997. Back to Bentham? Explorations of experienced utility. Quarterly Journal of Economics 112, 375-406. Kahneman, Daniel, Diener, Ed, Schwartz, Norbert (Eds.), 1999. Well-being. The Foundations of Hedonic Psychology. Russell Sage Foundation, New York.

Keser, Claudia, van Winden, Frans, 2000. Conditional cooperation and voluntary contributions to public goods. Scandinavian Journal of Economics 102, 23-39.

Kirchsteiger, Georg, Niederle, Muriel, Potters, Jan, 2005. Endogenizing market institutions: an experimental approach. European Economic Review 49, 1827-1853.

Klein, Benjamin, Leffler, Keith B., 1981. The role of market forces in assuring contractual performance. Journal of Political Economy 89, 615-641.

Krueger, Alan B., 2005. Well-being and policy evaluation. Presentation at the Econometric Society World Congress 2005, London, August 20, 2005.

Lane, Robert F., 1991. The Market Experience. Cambridge University Press, Cambridge.

Lane, Robert F., 2000. The Loss of Happiness in Market Democracies. Yale University Press, New Haven.

Lang, Peter J., 1980. Behavioral treatment and bio-behavioral assessments: computer applications. In: Sidowsky, J.B., Johnson, J.H., Williams, T.A. (Eds.), Technology in Mental Health Care Delivery Systems, NJ Ablex, Norwood.

Lawler, Edward, Thye, Shane, 1999. Bringing emotions into social exchange theory. Annual Review of Sociology 25, 217-244.

Lawler, Edward, Yoon, Jeongkoo, Baker, Mouraine, Large, Michael, 1995. Mutual dependence and gift giving in exchange relations. Advances in Group Processes 12, 271-298.

Levin, Jonathan, 2003. Relational incentive contracts. American Economic Review 93, 835-857.

Liebrand, Wim, 1984. The effect of social motives, communication and group sizes on behaviour in an N-person multi-stage mixed motive game. European Journal of Social Psychology 14, 239-264.

Loewenstein, George, 2000. Emotions in economic theory and economic behavior. American Economic Review, Papers and Proceedings 90, 426-432.

MacLeod, W. Bentley, Malcomson, James M., 1989. Implicit contracts, incentive compatibility and involuntary unemployment. Econometrica 57, 447-480.

McFadden, Daniel, 2005. The new science of pleasure. Frisch Lecture, Econometric Society World Congress 2005, London, August 20.

Niederle, Muriel, Vesterlund, Lise, 2007. Do women shy away from competition? Do men compete too much? Quarterly Journal of Economics 122, 1067-1101.

Offerman, Theo, Sonnemans, Joep, Schram, Arthur, 1996. Value orientation, expectations and voluntary contributions in public goods. The Economic Journal 106, 817-845

Okada, Akira, Riedl, Arno, 2005. Inefficiency and social exclusion in a coalition formation game: experimental evidence. Games and Economic Behavior 50, 278-311.

Rabin, Matthew, 1993. Incorporating fairness into game theory and economics. American Economic Review 83, 1281-1302.

Robinson, Michael D., Clore, Gerald L., 2002. Belief and feeling: evidence for an accessibility model of emotional self-report. Psychological Bulletin 128, 934-960.

Siegel, Sidney, Castellan Jr., N. John, 1988. Nonparametric Statistics. McGraw-Hill Book Company, Singapore.

Sonnemans, Joep (1991), “Structure and Determinants of Emotional Intensity”, Ph. D.-thesis, University of Amsterdam.

Sonnemans, Joep, van Dijk, Frans, van Winden, Frans, 2006. On the dynamics of social ties structures in groups. Journal of Economic Psychology 27, 187-204.

Stigler, George, 1987. In: The new Palgrave. A Dictionary of Economics, Eatwell, J., Milgate, M., Newman, P. (Eds.), The MacMillan Press Limited, London, pp. 531-535. 